\title{
The reflexive modernization of Australian universities
}

\author{
David Pick* \\ Curtin University of Technology, Perth, Australia
}

\begin{abstract}
The profound changes occurring in Australian higher education are viewed here in the context of the social, cultural, political and economic effects of globalization. Particular attention is paid to providing a theoretical foundation for understanding these effects using the reflexive modernization perspective. Highlighted are some of the challenges facing universities in Australia brought about by the corrosive influences of individualization and risk. This paper includes a call for a more critical and intentional approach to higher education policy and management.
\end{abstract}

\section{Introduction}

In discussing the theory of reflexive modernization, Beck argues that industrial society is being dissolved and replaced by a new modernity and globalization is the process driving this transformation in that it is 'changing the foundations of living together in all spheres of social action' (Beck, 1998, p. 17). However, both reflexive modernization and globalization have been subject to wide ranging discussion and debate. Globalization is 'deeply contested along a number of dimensions' (Clark, 1998, p. 498), and reflexive modernization is seen by some as being theoretically flawed (Alexander, 1996). Many agree that both reflexive modernization and globalization are surrounded by imprecision and conceptual confusion (Beck, 1998; Dannreuther \& Lekhi, 2000). They are, however, key ideas that may help generate greater understanding of the multi-dimensional social, economic, political and cultural transformations currently taking place (Clark, 1998). Moreover, both have become major ideas informing policy development around the world (Dannreuther \& Lekhi, 2000).

Globalization has brought about significant changes to universities across the globe, changes that have been examined in numerous studies. These studies show variations in the effects and responses of individual institutions and governments. It is yet to be established how the contradictory forces of the global-local nexus will be

* Curtin Business School, Curtin University of Technology, GPO Box U1987, Perth 6845, Australia. Email: d.pick@curtin.edu.au 
played-out in higher education. However, the empirical evidence suggests that these effects will be profound. As Readings (1996, p. 2) concludes, 'the wider social role of the University is up for grabs. It is no longer clear what the place of the University is within society nor what the exact nature of that society is, and the changing institutional form of the University is something that [we] cannot afford to ignore'.

The responses of universities to globalization have been far from uniform either in the ways academic work is organized or the framework within which universities operate. This international variation is mainly due to the social, economic, political and cultural environment specific to each national context that impacts on how universities respond to globalization (Deem, 2001). In the West, there is evidence of convergence in the higher education policies (Slaughter, 1998). Currie et al. (2003) report that globalization is having an influence on the practices of both the North American and European contexts. This convergence is reflected in: a growing relaxation of government control, emphasis on economic competitiveness, the channelling of resources into curriculum areas that meet the needs of the global marketplace, a focus on preparing students for being part of a global workforce, and creating efficiencies in the management of the universities. These trends are not however, reproduced worldwide. In contrast to the de-regulation experienced by Western universities, reregulation has been the norm in some countries. In Singapore and Hong Kong, for example, government control over universities has been expanded (Mok, 2000) and in China, universities have so far resisted global trends in favour of local values (Yang, 2000). Given the international differences in culture, organization, policy, etc. between higher education systems, the influences of globalization might be similar but the outcomes are quite different due to the complex interplay of the local and the global.

It is not surprising then that higher education in Australia has been significantly affected by globalization (Pratt and Poole, 2000). However, 'globalization processes in higher education are under-studied and under-theorized' (Marginson $\&$ Rhoades, 2002, p. 281). As key locations for the development of the knowledge industries of global capitalism (e.g. education and training, legal and advisory services, research and development, electronic information management, telecommunications), universities have experienced rapid and profound change over the past few decadeschanges that are radically redefining the nature and purpose of higher education. These changes are conceptualized in this article as a reflexive modernization of higher education.

\section{Globalization}

There is an extremely wide body of literature devoted to the topic of globalization. It has therefore been necessary to be selective. Held et al. (1999) provide a useful, recent analysis of globalization. This work presents one of the most in-depth, empirical, and theoretical overviews currently available (Lynch, 2001).

Held et al. (1999) identify three interpretations of globalization: 'the hyperglobalist thesis', 'the sceptical thesis' and 'the transformationalist thesis'. According to the 
hyperglobalist thesis, globalization marks the dawn of a new epoch characterized by the inevitable and positive consequences of the worldwide triumph of free-market capitalism and Western liberalism. 'The world is seen to be converging towards a single system of capitalist economic governance and globalization is seen to be an inevitable and thoroughly positive part of that process' (Dannreuther \& Lekhi, 2000, p. 583).

Representatives of this view include Friedman (1999) and Ohmae (1995). These authors argue that the global economy is increasingly the most important driving force in human affairs, whilst nation states are becoming by-standers to a marketdriven globalization. Those who adopt a hyperglobalist perspective consider nation states as being in retreat if not already redundant, yielding to the authority of international institutions - for example, WTO, IMF, World Bank etc.-as the only truly effective regulatory organizations at the global level. At the same time, regional regulation is ensured by regional groupings of nations - for example, NAFTA, EU, ASEAN etc. (Dannreuther \& Lekhi, 2000)

Critics of the hyperglobalist position argue that rather than being an autonomous process driven by markets and technology, globalization reflects actual relations and distributions of power between individual nation states. Clark (1998) contends that the hyperglobalist position misses the point: nation states are not only the vehicles of globalization, but are also reconstituted by it through a discontinuous and reversible process that is politically driven and sustained. Indeed, Beck (2000) and Zincone and Agnew (2000) argue that the hyperglobalist thesis is grounded in neo-liberalism-the high politics of hyperglobalism - even though it presents itself as being non-political. For Zincone and Agnew (2000), this means globalization is a new form of imperialism: the application of world market laws that must be implemented and obeyed according to neo-liberal interpretations. In the hyperglobalist view, politics and economics are fused into one. The hyperglobalists assert a neo-liberal, oligarchic, laissez faire faith (rather than logical argument) - the belief that firms and people in nation states are joined in a community of fate marching towards inevitable globalization under the sovereign banner of the free-market. The free-market is seen as a natural benevolent process free of politics and beyond criticism. As a result, the hyperglobalist thesis tends to paralyse political debate and action. If we take the view that nothing can be done to control the march of globalization, 'then the only response in the end is to take cover and hide oneself away' (Beck, 2000, p. 125).

The sceptical or state-focused thesis stands in opposition to the hyperglobalist position (Dannreuther \& Lekhi, 2000). Held et al. (1999) argue that authors who advance the sceptical thesis point to a lack of empirical evidence regarding the impacts of globalization on the day-to-day practices of national economies. Scholars such as Hirst and Thompson (1996) and Kapstein (1994) contend that national governments continue to have considerable power to regulate the forces of the global economy, and that this power is enhanced by entering regional trading blocs. Indeed, Weiss (1998) and Kleinknecht and ter Wengel (1998) suggest that globalization is a myth. They argue that the evidence put forward about globalization is often anecdotal, and go on to point out that the forces behind regionalization and localization 
may be stronger than those for creating greater interdependence and globalization. Globalization sceptics do not consider the nation state to be redundant nor do they believe that national economies are converging. Instead, the nation state is placed at the centre of economic development. Nations are still sovereign and able to place controls on capital, protecting them from the excesses of unfettered capitalist accumulation that might occur in a de-regulated, globalized world (Dannreuther \& Lekhi, 2000).

In spite of the arguments put forward by the sceptics, many authors point out that the empirical reality of globalization is difficult to refute. What is debatable, however, is the extent and nature of that reality. Whilst the hyperglobalist and state focused views of globalization are positioned at odds with each other, both have valid arguments to make. The hyperglobalist is correct in arguing that at the national level, transnational networks and international forces are becoming increasingly important. On the other hand, the state focused view includes the valid claim that this does not mean nation states have diminished in importance or relative independence (Hirst \& Thompson, 1996). Beyond this though, Dannreuther and Lekhi (2000) conclude that both have missed the central point of globalization. The assumption is made by these rival positions that current relationships between nations states and markets will continue to exist into the future. Both the hyperglobalist and sceptical positions are severely limited in their analytical usefulness. They both imply that globalization will lead to some kind of predictable end state and rely on similar, narrow economic approaches to support their claims (Perraton et al., 1997). However, globalization is far more complex. It is allowing new links to be established across social, political, cultural, and economic boundaries that do not correspond to the old hierarchies (Beck, 2000). Perraton et al. (1997) and Clark (1998) call for an approach that can capture globalization as a multi-dimensional, historical process, which recognizes the uncertainty of its outcomes and the counter-pressures exerted by both the emerging global system and individual nations. For Perraton et al. (1997), globalization is a process that includes economic, political, social, legal, cultural, military and technological aspects, all of which must be adequately taken into account.

Given the inadequacies of these two influential accounts of globalization, Held et al. (1999) have developed the transformationalist thesis as a response to the need for an alternative approach. They state that 'at the heart of the transformationalist thesis is a conviction that, at the dawn of a new millennium, globalization is a central driving force behind rapid social, political and economic changes that are reshaping modern societies and world order' (Held et al., 1999, p. 7).

The transformationalists are more guarded about drawing conclusions about the direction and effects of globalization. However, they are in no doubt that it is bringing about massive shifts in domestic and international affairs. According to the transformationalist thesis, globalization is composed of a complex set of processes, variable in their effects and full of paradoxes and ambivalences sometimes working in opposite directions. For example, as nation-states weaken in the face of globalization, previously latent nationalistic tendencies are re-emerging in response to globalizing influences as a way of protecting local cultures. 
Globalization is more than just about trade and commerce, it is a process of deep social, cultural and economic change from which the contours of a global order are beginning to emerge. It is a process that is weakening the familiar institutions and structures that currently organize societies in a largely unpredictable and discontinuous way that will perhaps only be fully understood in hindsight.

\section{Reflexive modernization}

Reflexive modernization is a transformationalist account of globalization in that it includes far-reaching and deep changes to national, regional and international institutions. The reflexive modernist argues that such wide-ranging reforms of existing institutions and approaches to political and economic governance are needed to ensure their relevance in an era of globalization (Dannreuther \& Lekhi, 2000). The leading proponents of this approach are Giddens $(1991,1994)$, Beck $(1998,2000)$ and Lash (1999). In essence, the reflexive modernization interpretation of globalization conceptualizes the phenomenon as a continuation of modernity rather than as a continuation of capitalism (Beck, 2000). In the hyperglobalist perspective, the global economy is the most important driving force in human affairs, whilst nation states are considered to be in retreat if not already redundant, yielding to the imperatives of the functioning of an emerging global market. In contrast to this, reflexive modernization includes a central role for the nation state in realizing the functional requirements of globalization in the form of intensifying interdependencies within international alliances and organizations (Dannreuther \& Lekhi, 2000).

These connections between the national and the global may be described as the 'global-local nexus,' (Beck, 2000) or as 'glonacal agency' (Marginson \& Rhoades, 2002). According to Beck (2000), globalization and localization are two sides of the same coin in that globalization not only leads to de-location, but also to relocation. For example, firms cannot immediately produce and sell their goods and services globally. They must first develop local connections so that their product has a viable local market geared to particular local characteristics and tastes. Global in this sense means in many places at the same time. In this way, the global-local nexus refers to processes in which local traditions, companies, lifestyles, and so on become relocated within a global context where they must be justified, shaped and renewed. Marginson and Rhoades' (2002) notion of glonacal agency adds the national dimension missing from Beck's account. They believe that globalization has not rendered the nation state insignificant. They also maintain that neither globalization nor the nation state have undermined completely the local dimension. As they explain, 'in presenting our glonacal agency heuristic, we emphasize the intersections, interactions, mutual determinations of these levels (global, national and local) and domains (organizational agencies and the agency of collectivities). We do not see a linear flow from the global to the local .... At every level - global, national and local—elements and influences of other levels are present' (Marginson \& Rhoades, 2002, p 288).

Thus for both Beck (2000) and Marginson and Rhoades (2002), globalization is conceptualized as a multi-directional and multi-dimensional phenomenon. For 
example, communications technology, ecology, work organization, culture, and civil society are all implicated in processes of globalizing transformation; a criss-crossing of sovereign nation states by global actors with varying levels of power, orientations, identities and networks. Beck (2000) argues that that the idea of being able to live and act in the self-enclosed spaces of nation states and their national societies is being dismantled. Under these circumstances, people are thrown into transnational lifestyles that they sometimes neither want nor understand. Globalization is creating a situation where we must live together over distances across apparently separate worlds of nation states, regions and continents.

Two major features of the reflexive modernization perspective are: individualization and risk. Individualization is a process which refers to the 'exhaustion, dissolution and disenchantment of the collective and group specific sources of identity and meaning of industrial societies' (Beck, 1998, p. 32). Individualization creates a situation where people become flotsam or jetsam. Those who adapt and become reflexive and self-monitoring survive and sometimes prosper, but at the cost of becoming flotsam, swept along by the currents of globalization. Those who cannot or do not wish to adapt are discarded from the mainstream and become jetsam (conspicuous are the permanently unemployed poor, the working poor, and those living in marginal areas). Of special relevance here is the idea that education is a major element determining a person's life chances, as Beck and Beck-Gernsheim (2002, p. 32) point out, 'education in schools and universities ... provides individual credentials leading to individualized career opportunities'. Education is also one of the key social sectors where a global market has formed. Many of the effects of globalization can be seen in higher education, and universities are key players in the structuring of global relationships (Marginson \& Considine, 2000).

The significance of individualization is that it enables the invention of new forms of life which are characterized by individualism. The connection between individualization and individualism lies in the view that society is a collection of individuals who have the freedom to produce and consume in a free market situation. The difference between the two is that individualization is a set of processes whereas individualism is a theoretical perspective. Beck and Beck-Gernsheim's (2002) employ the concept of institutionalized individualization to describe the process whereby individuals whilst living their own, separate lives are nonetheless connected to each other through social, economic and political institutions and structures. What Beck and Beck-Gernsheim do not examine though is the relationship between individualization and individualism. This relationship can be seen as working in two directions. First, institutionalized individualization can be seen as being a set of processes associated with institutionalized individualism. That is institutions are acting as mediators in the relationship between individuals and wider society. Secondly institutionalized individualism can be seen as based on the idea that economic arrangements, social institutions and political mechanisms are fundamentally a function of the free action of individuals. Institutions can thus be seen as being both mediators of, and dependent on, the collective actions of individuals. We are confronted with a binding together of individuals and institutions in complex 
and sometimes paradoxical relationships. Individualization implies a dependence of individuals on the actions of institutions whilst individualism implies a dependence of institutions on the actions of individuals.

This problematic relationship between people and institutions is elegantly summarized by Beck and Beck-Gernsheim (2002 . p. 22) as living 'a life of one's own in a runaway world'. People's lives are being broken-down into separate functional spheres making them only partly integrated into society through its institutions as students, voters, taxpayers, car drivers etc. They are therefore dependent on those institutions that facilitate these interactions (universities, taxation office, government agencies etc.). There is a paradox here in that people's lives are differentiated and at the same time standardized by the legalities and norms set by society's institutions. So, it may be argued that individualization results in people living non-identical lives that are mediated through institutions (Beck \& Beck-Gernsheim, 2002).

Two key aspects of individualization are disembedding (Beck \& Beck Gernsheim, 2002) and re-embedding (Beck, 1994). Disembedding is a consequence of the individualizing effects of modernization (e.g. civil, political and social rights, and education) that leads to the development of fully self-monitoring individuals who are required to develop their own biographies based on one's own personal resources and abilities. This disembedding marks the transformation from simple modernity (a mixture of self-monitoring and heteronomous monitoring) to full or reflexive modernity (more consistent reflexive self-monitoring) (Lash, 1993).

This process of disembedding and re-embedding involves first, the disembedding of ways of life and second, the re-embedding of new ones in which individuals must produce and stage their own reflexive biographies. Individualization may involve the freeing of individuals from the structures of industrial society so that they are selfmonitoring, but the process of individualization is forced upon people by the very process of disembedding (Beck, 1994). This is because disembedding means that the remaining taken-for-granted heteronomous structures of simple modernity that formerly defined peoples' lives (e.g. class, gender, family, politics etc.) are dismantled and replaced by heterodoxical contingencies (Lash, 1993).

The effects of reflexively modernizing globalization are further detailed by proponents of reflexive modernization using the concept of risk. This has been produced as modern industrial society creates unintended side-effects. 'Its central themes and perspectives have to do with fabricated uncertainty within our civilization: risk, danger, side-effects, insurability, individualization and globalization' (Beck, 1996, p. 1). Beck conceptualizes risk arising from global ecological problems, however, it can also be seen as arising from the direct but unintended and unforseen social, economic, political and cultural effects of globalization. Risk has forced people into situations of rule-finding, and reflexive or indeterminate judgment as they try to deal with these unintended and often unforeseen effects of globalization.

Individualization and risk together point to a gradual breaking-down of existing political, social and cultural institutions and arrangements leaving people in a state of chronic disembeddedness. They must create their own biographies whilst at the same time being faced with social, cultural and economic 'risks' which they must respond 
to using their own personal resources; they can no longer rely on government to provide socially funded health services, security, education etc. This interplay between individualization and risk thus raises the question about the role of national government in controlling people's lives and forces us to consider the notion of governmentality (self-government) as well as government. National government and self-government can neither copy nor replace one another but they do interact, waxing and waning depending on the situation. Self-government gains ground in spheres where national government is perceived to be failing (e.g. family, security, health, environment). These were originally maintained by the state on behalf of all citizens through universal measures ranging from a socially funded police force, social insurance etc. (Rose, 1999). Now, personal responsibility and choice are the drivers of maintaining these spheres as people are forced to take control of their own fate.

The circumstances in which the power of government can be deployed are being transformed by reflexively modernizing globalization. It has widened the range of sites government operates beyond the confines of national and local state agencies whilst at the same time narrowing its power over individuals within a nation. This paradox forces us to consider how power and knowledge is deployed in contemporary societies; the different ways power is exercised over individuals and society in a search for ways to reconcile the needs of individuals and the collective (Rose, 1999).

There is no doubt that the reflexive modernization perspective has been a highly influential and original formulation. However, there are several areas around which criticism has been focused. In particular, three main themes are evident in the literature: an over-emphasis on the transformational power of risk, reconciling reflexivity and reflection, and that too much prominence is given to modernity.

Reflexive modernization is limited in its grasp of the social construction and reconstruction of risk to the extent that it has been described as deeply flawed, utilitarian and objectivist (Alexander, 1996) and as essentially one-sided in the sense of being cognitive and not sufficiently sensitive to culture (Strydom, 1999). Elliott (2002, p. 301) maintains that this is because reflexive modernization 'cannot grasp the hermeneutical, aesthetic, psychological and culturally bounded forms of subjectivity and intersubjectivity in and through which risk is constructed and perceived'.

In maintaining that regardless of social class we are all united in a community of fate, Beck claims that class consciousness is eroded since we are all equally threatened by the same, inescapable global risks (e.g. global warming, ozone depletion, species extinctions). Sooner or later, risks catch up with those who profit from them causing a kind of equalizing effect. We are thus all confronted similarly by the risk-fate of industrial modernity. However, as Elliott (2002) points out, Beck does not adequately account for how individuals are drawn into the processes of reflexive modernization (e.g. individualization) which may embody the asymmetrical power relationships of social class evidenced in the emerging gap between information-rich and information-poor communities and the socially excluded underclass. Social inequality and social division rather than being equalized by risk may be being accentuated. 
Reflexive modernization may also be criticized for assuming a modernist perspective. The main thrust of reflexive modernization theory is that society is going through a period of transition to a new modernity and may thus be seen as a continuation of modernity. This though excludes the possibility that individualization and risk may be propelling us beyond modernity and therefore underplays the role of wider institutional and epistemological factors in this transition (e.g. the levelling of social hierarchies and the fracturing of knowledge claims) whilst privileging the concepts of risk, reflexivity and individualization (Elliott, 2002). Furthermore, reflexive modernization includes the idea that the transition to a new modernity is taking place unintentionally and unseen by the major categories and theories of industrial society (including the globalization controversies outlined earlier). In the theory of reflexive modernization, industrial society dissolves as people bring into question and try to tackle its unintended side effects. This is not the catastrophic process of political crisis, economic meltdown and the collapse of global economic structures typically imagined by modern social theorists. From Beck's (1992) perspective, just as theoretical understandings of modernization conceptualizes the dissolving of traditional society and the rise of modern industrial society, the theory of reflexive modernization is conceptualizing the dissolution of industrial society and its gradual transformation into a new kind of modern.

Problems also arise in the way reflexivity and reflection are treated as separate phenomena in reflexive modernization theory. The 'reflexivity' of reflexive modernization implies unthinking and unknowing responses to modernization whilst the 'reflection' of reflexive modernization refers to a deliberate (knowing) response to the unintentional and unseen (reflexive) dissolution and endangerment. However, reflection does not necessarily follow-on from reflex. As Elliott (2002) points out, the problem here is that in splitting reflexivity and reflection into mutually exclusive categories, Beck has separated blind social processes and practices (reflex) from knowledge residing with social actors (reflection). Rather than reflex and reflection being separate, they are bound together in a complex relationship requiring the development of more heterogeneous, interpretive analytical methods.

In sum, reflexive modernization may be criticized for proceeding from a modernist perspective, from which a utilitarian methodological approach is an inevitable consequence, neglecting interpretive knowledge and culture, whilst placing too much emphasis on risk and ignoring the connections between reflexivity and reflection. Such problems have led Lichtblau (1999) to maintain that the concept of reflexive modernization lacks theoretical ambition and cannot be taken seriously as it fails to reconcile the social and cultural worlds, and lacks an account of the specific aesthetic experience of modernity.

However, in a time when we are confronted with paradox, contradiction and uncertainty, novel ideas, insights and methods are needed. Reflexive modernization is particularly useful in this respect with regard to examining the effects of globalization on higher education. It can help us begin to explore the connections between the global, national and local contexts enabling these different levels of influence to be integrated and understood in their entirety. 


\section{The reflexive modernization of Australian universities}

Whilst there is little published research relating to reflexive modernization and Australian universities, there is a large body of research that points to globalization as a fundamentally important driver of reform to the higher education sector (Pratt \& Poole, 2000). From a governmental perspective, this refers to a deployment of a neoliberal interpretation of globalization by the Australian government to higher education policy since the 1980s. At the heart of this interpretation is the encouraging of a neo-liberal reform process which is represented by the shift from Keynesian full employment policies to sound financial policies (low inflation, sustainable debt repayment, avoiding excessive government deficits etc.) accompanied by a focus on supplyside issues emphasizing market forces, an open-market economy and competition (Bell, 1997). This trend towards the pursuit of neo-liberal policies has been comparatively strong in Australia compared to other OECD nations, especially in terms of speed and breadth of implementation. There has been an almost overwhelming influence of neo-liberalism in the policies of successive Australian governments beginning in the mid-1980s with the Hawke Labor government and continued apace by the Howard Coalition government elected in 1996 (and subsequently re-elected in 1998 and 2001).

The Howard Government, embarked upon reform of higher education in Australia that included a series of significant cuts to government support for the sector. Government funding has dropped from $\$ 4.3$ billion in 1995 (Department of Education, Science and Training, 1997) to $\$ 4.1$ billion in 2001 (Department of Education, Science and Training, 2003). Accompanying this was a policy review process that began with the West Report (1997). This report was based on the premise that the existing system was under stress and that change was 'unavoidable and urgent' (West, 1997 , p. 2). The West Report was supposed to herald a new direction for higher education policy. However there was no follow-up White Paper, signalling a stalling of the policy process. In 2002, the Howard Government embarked on another review of higher education. The Minister for Education, Science and Training has recently published a series of discussion papers (e.g. Nelson 2002a,b) with a policy paper to follow. These discussion papers underline the process of change that is characteristic of higher education in Australia. The first discussion paper (Nelson, 2002a) outlines a series of principles for higher education that emphasize the development of selfgoverning universities and self-governing individuals working and studying at universities combined with steering at a distance by government. Self-governing universities are encouraged through the promotion of high quality, flexibility, and accountability which in the neo-liberal policy discourse take on particular meanings. High quality, in the context of the Nelson review, is formulated from a set of criteria designated by government appointed experts and refers to ranking within the system rather than an externally referenced idea. High quality then refers to those institutions most aligned with government thinking (i.e. steering at a distance). Flexibility in the Nelson context means deregulation, marketing, and rule by incentives, targets, plans and funding formulae (promoting self-governing universities). These themes are developed further 
by Nelson (2002b) where fee deregulation and a student voucher system is openly canvassed (promoting self-governing individuals through increased choice).

In spite of continued economic growth, government surpluses, and a recognized need for qualified and educated people to sustain such growth in the emerging knowledge economy, the Australian Government continues to pursue a policy trajectory that is effectively a decision to let globalization run its course without intervention. The universities, powerless to do otherwise, are responding reflexively to this uncertain environment.

In the language of reflexive modernization theory, not only are Australian universities one of the mediating agents of individualization and individualism, they themselves are undergoing a similar process at an institutional level. Furthermore, reflexively modernizing globalization has created a risk environment to which they must adapt.

In terms of individualization, two aspects are relevant to this analysis, these are: disembedding and re-embedding. In a study of the modern vision of the Australian university of the 1950s and 1960s, McCalman (2000) argues that this vision has been blurred or diluted by recent policy developments, leading to a crisis of identity. They are undergoing a process of reflexive change in which a crisis of identity and legitimacy brought about by globalization has led to the progressive disembedding of Australian universities from the heteronomous structures of society that originally defined them-structures such as discipline boundaries, professional rules and academic independence. This process of disembedding, driven, in part by the universities themselves has meant that the fundamental raison d'être of the university is itself being questioned (Readings, 1996; Coady, 2000).

Also, universities are being disembedded from the older national policy framework as defined by the Murray Report (1957) and the Martin Report (1965). The reports associated universities with the broad social, economic and cultural nation building project implying that universities were pursuing a common public purpose in the development of the nation. The view was that the total benefit to society through having a highly education population were far higher than the total private gains to those who gain a university education (Marginson \& Considine, 2000). However, since the mid-1980s, beginning with the Dawkins Report (1988) and ending with the Nelson Report (2002a) there has been a significant policy shift which has disembedded Australian universities from their role as vehicles of national cultural, social and economic development, focussing instead on the economic value of outputs and the private benefits people accrue from a university education. They have been progressively re-embedded into a new policy framework that views universities as contributors to Australia becoming a lean, mean global competitor.

Disembedding is also evident in the way universities are changing their form, culture, role, and relationships. Universities are becoming more self-governing, so too are the people working within them. In this case, disembedding is manifest in the erosion of academic freedom, independence and collegiality. From their study of universities in Europe, North America and Australia, Currie et al. (2003) identify the wearing away of tenure as a key factor in undermining academic freedom and independence. This 
has been the result of the implementation of managerialist approaches to university management and the marketization of the higher education system in line with the World Bank's view that universities become globally competitive by being less dependent on government funding, de-regulated and exposed to market forces. Such changes in the governance of universities towards managerialism and marketization is reflected in the way decision-making is increasingly centralized with senior management in universities seeing themselves as chief executive officers of multi-million dollar businesses (Marginson, 2000a). As a result, prevailing forms of governance and academic work in Australia's higher education system are under direct assault from the requirement to serve markets, emulate private corporations, engage with the global education market, and meet the demand from government to do more with less (Marginson \& Considine, 2000). This emphasis on becoming more like a profit-making corporation is a reminder that higher education is now seen more as a cost than an investment (Lafferty and Fleming, 2000) - a reminder borne out as the proportion of university funding received from the federal government in Australia dropped from 57\% in 1985 (Department of Education, Science and Training, 1987) to 44\% in 2001 (Department of Education, Science and Training, 2003).

This trend towards self-government has also resulted in the dilution of collegiality. This aspect of disembedding can be seen in an erosion of the sense of identity felt by people working in Australian universities to the point where Winter and James (2000) identify a feeling of psychological disconnection of academics from their institutions. At this micro-level, the solidarity of collegiality has been compromised by significant downsizing and radical changes to staff working conditions which have occurred as a response to marketization, funding reductions, and the intensification of competition between universities. Academic and general staff are increasingly being casualized, expected to undertake heavier workloads, and endure less job security (Marginson, 1993; Smyth, 1995; McCollow \& Lingard, 1996; Coaldrake \& Stedman, 1998). What is more, the erosion of collegiality is destroying the community of scholars that used to define the university (Brett, 2000). In this sense then, the Australian university is becoming a place without a community. As a consequence, the way of life of the university academic has become disembedded, in spite of resistance to this trend. But the other side of this disembedding is also evident so that, for better or worse, there is a re-embedding of university academics into self-governing, individualized work cultures based on competition, fixed-term contracts, and individually negotiated conditions of service.

The evidence here suggests that universities are now in the process of re-embedding themselves into new forms of life. Australian universities are becoming consistently more reflexive and self-referential. As a result, the re-embedding of the institutions and those working within them is creating a new set of cultures and practices in which the universities themselves are much like private companies, emphasizing accountability to stakeholders, customer focus, profit and loss etc. The resulting focus of the new university boards of directors (university councils) on self-monitoring practices, review and reporting may mark the transition to full modernity as universities become entirely different institutions. 
The second key aspect of the reflexive modernization of Australian universities is the condition of risk brought about by globalization. This results from the dissolution of the structures of the old modernity, leading to the move towards self-monitoring, self-government and constant re-invention. For universities, this uncertainty is manifest for the most part in the insecurity of future income. Pratt and Poole (2000) identify this phenomenon at the institutional level, stating that universities have no option but to continually rework themselves in order to function effectively in the emerging international education market place where flux and uncertainty are brought about by the dynamic and complex forces of globalization. These responses are focused on short-term self-monitoring and self-adaptation, rather than a clear long-term vision. At the institutional level universities are constantly adapting and changing in order to survive and prosper in an uncertain environment of limited public funding and increased international competition. As a result, universities, their employees, and other stakeholders are in the grip of a debate about the nature and future of higher education in Australia (Coady, 2000).

Universities are also experiencing risk in the sense that they are being affected by many factors that are beyond their control (e.g. government policy, international education market conditions) but as self-governing institutions, their own actions will be decisive in determining their future success or failure. This is unlike the past when government support cushioned universities from the grim reality of competition. As a result, Australian universities are becoming more anxious and unstable institutions who are responding to risks with a 'combination of managerial aggression, academic falter and plastic imitation' (Marginson \& Considine, 2000, p. 244). Imitation also carries with it further risk in that the universities are in jeopardy of losing the characteristics that enable them to make distinctive contributions and, as with Western universities generally, global convergence is pushing Australian universities into the mould of a single model based on what an idealized American university might look like. But far from achieving any such ideal, if Australian universities follow this trend they will become weak, second-class imitations of American universities (Marginson, 2000c).

These consequences have been serious and probably unforeseen (Currie, 1998). Australian higher education is undergoing a period of reflexive modernization requiring policy responses that are more aware of the governmental issues and organized to resist the negative effects of globalization as it forces universities to become more market oriented. Managerialsim has re-worked the academic's role and function and in Australia has marked the emergence of a neo-liberal induced extreme case which Marginson and Considine (2000) call the 'enterprise university'. The enterprise university works around or against academic cultures in a zero-sum struggle between entrepreneurs and scholars rather than engaging in the more subtle development of relationships between the two. In particular, this struggle is manifest in the perception that academic professionalism is being threatened by entrepreneurial activities through: the lowering of academic standards, a loss of independence in academe, and the pressure to become more like corporate professionals (Pratt \& Poole, 2000). This mismatch between the emerging university work structures and academics' values 
and expectations, the rise of business related managerial practices, high levels of work overload and low levels of academic participation in decision making are compromising staff morale in universities (Winter \& Sarros, 2000).

This divergence of cultures within universities is clearly evident in the increasing power of administrative managers in universities combined with the silencing of robust academic dissent, discussion and debate (Patience, 2000). The events surrounding the publication of the edited work by Coady (2000) are an example. The book was originally commissioned by the University of Melbourne, which agreed to publish the work through its publishing house, but later changed its mind. According to Fraser (2000), Melbourne University Press would not publish the book because of the highly critical stances taken by many of the authors to current government policies and management practices in universities. The book was eventually published by Allen and Unwin amid much controversy in the higher education sector and public comment in the mass media.

The themes just discussed are well developed in the Australian-based literature, which point to a general agreement that universities in Australia are being transformed by profound long-term changes that have accelerated since the late-1980s as they encounter global corporate systems of organization (Marginson, 2000b; Marginson \& Considine, 2000). As Currie (1998, p. 9) sees it, 'we are being swept along by these ... trends.' Australian universities are now at a critical point in their history (Coaldrake \& Stedman, 1998). Squeezed between federal budget cuts to higher education and an increasingly unfamiliar environment, higher education in Australia is struggling to keep up with technological developments and their social, economic and cultural side effects. Moreover, the accelerating globalization of higher education through the on-line delivery of courses is adding to the pressure on universities to form strategic partnerships and to expand their operations to achieve economies of scale.

The current policy situation of inactivity — of leaving universities to tackle the challenges facing them without government direction or additional funding - is leading to a point where 'the future is largely in our own hands' (Coaldrake, 2000, p. 21). This view is consistent with Lash's idea that we must 'find the rules to encounter specific situations' (Lash, 1993, p. 3). Australian universities are finding themselves in a situation where they must redefine themselves and adapt to the changing environment or be overwhelmed (Coaldrake \& Stedman, 1998).

\section{Conclusion}

This analysis of Australian universities has a number of implications. Universities are responding to reflexively modernizing globalization by employing a managerialist agenda emphasizing accountability, central surveillance, compilation of reports, responses to reviews, data gathering etc. This is arguably a feature of higher education not just in Australia but worldwide.

Reflexive modernization has proved useful a useful critical framework for analysing the effects of globalization on higher education in the Australian context. It provides 
a way of characterizing the dynamic and varying experiences of globalization within which universities are being forced to constantly change. It does this primarily by providing the particularly useful and interrelated concepts of individualization and risk, both of which help to illuminate the complex governmental issues at work.

The reflexive modernization of Australian universities is characterized by the emergence of more self-governing, more fragile, more leader-dependent and less selfreproducing institutions, resulting in the potential loss of their identity as centres of higher learning and research (Marginson \& Considine, 2000). It can be argued that Australian universities are becoming more and more reflexive, making it difficult to respond within existing organizational structures and arrangements. Marginson and Considine (2000) point out that higher education institutions in Australia are constantly having to reinvent themselves to become: more entrepreneurial (as seen in the development of marketing to fee-paying overseas students), more globalized (with off-shore campuses or internet-based courses), and more specialized (perhaps in distance education and flexible learning) and at the same time more generic. The universities are aggressively marketing an image of distinctiveness whilst following a path leading to educational conformity.

An effective response to these trends is to counterbalance the growing reflexivity in the governance and management of universities in Australia with an approach that intentional and facilitative, coupled with self-criticism and action (Marginson \& Considine, 2000). What is alluded to here is that whilst accepting a degree of selfreference, there would nonetheless be efforts to help counter the negative effects of reflexively modernizing globalization. Without such an approach that is simultaneously intentional and critical, the consequences of action might unwittingly result in an intensification of this trend. Australian universities are becoming truly modern through a process of disembedding from the heteronomous control of structures and a subsequent process of re-embedding into self-monitoring, reflexive forms. However, the picture is complex, as the reflexive modernization view of globalization suggests. More research is needed focusing on the usefulness of the reflexive modernization perspective for examining the processes of change affecting universities in other national contexts.

\section{Note on contributor}

David Pick is a Lecturer in Management at Curtin Business School, Curtin University of Technology. He recently completed a $\mathrm{PhD}$ with Murdoch University which focuses on testing the usefulness of reflexive modernization and frame analysis in creating a framework for understanding organizational change in the context of globalization.

\section{References}

Alexander, J. C. (1996) Critical reflections on 'reflexive modernization', Theory, Culture and Society, 13, 133-138. 


\section{D. Pick}

Beck, U. (1992) Risk society: towards a new modernity (London, Sage).

Beck, U. (1994) The reinvention of politics: towards a theory of reflexive modernization, in: U. Beck, A. Giddens \& S. Lash (Eds) Reflexive modernization: politics, tradition and aesthetics in the modern social order (Cambridge, Polity Press).

Beck, U. (1996) World risk society as a cosmopolitan society? Ecological questions in a framework of manufactured uncertainties, Theory, Culture and Society, 13, 1-32.

Beck, U. (1998) Democracy without enemies (Cambridge, Polity Press).

Beck, U. (2000) What is globalization? (Cambridge, Polity Press).

Beck, U. \& Beck-Gernsheim, E. (2002) Individualization: institutionalized individualism and its social and political consequences (London, Sage).

Bell, S. (1997) Globalization, neoliberalism and the transformation of the Australian state, Australian fournal of Political Science, 32, 345-367.

Brett, J. (2000) Competition and collegiality, in: T. Coady (Ed.) Why universities matter: a conversation about values, means and directions (St Leonards, Allen \& Unwin).

Clark, I. (1998) Beyond the great divide: globalization and the theory of international relations, Review of International Studies, 24, 479-498.

Coady, T. (2000) Universities and the ideals of inquiry, in: T. Coady (Ed.) Why universities matter: a conversation about values, means and directions (St Leonards, Allen \& Unwin).

Coaldrake, P. (2000) Reflections on the repositioning of the government's approach to higher education, or I'm dreaming of a White Paper, fournal of Higher Education Policy and Management, 22, 9-21.

Coaldrake, P. \& Stedman, L. (1998) On the brink: Australia's universities confronting the future (St Lucia, University of Queensland Press).

Currie, J. (1998) Introduction, in: J. Currie \& J. Newson (Eds) Universities and globalization: critical perspectives (Thousand Oaks, CA, Sage).

Currie, J., DeAngelis, R., de Boer, H., Huisman, J. \& Lacotte, C. (2003) Globalizing practices and university responses: European and Anglo-American differences (Westport, CT, Praeger).

Dannreuther, C. \& Lekhi, R. (2000) Globalization and the political economy of risk, Review of International Political Economy, 7, 574-594.

Dawkins, J. S. (1988) Higher education: a policy statement (Canberra, Commonwealth of Australia).

Deem, R. (2001) Globalization, new managerialism, academic capitalism and entrepreneurialism in universities: is the local dimension still important? Comparative Education, 37, 7-20.

Department of Employment, Science and Training (1997) Selected Higher Education Finance Statistics (Canberra, Commonwealth of Australia).

Department of Employment, Science and Training (2003) Selected Higher Education Finance Statistics (Canberra, Commonwealth of Australia).

Elliott, A. (2002) Beck's sociology of risk: a critical assessment, Sociology, 36, 293-315.

Fraser, M. (2000) Afterword: the body in question, in: T. Coady (Ed.) Why universities matter: a conversation about values, means and directions (St Leonards, Allen \& Unwin).

Friedman, T. (1999) The lexus and the olive tree (New York, Farrar, Straus \& Giroux).

Giddens, A. (1991) Modernity and self identity: self and society in the late modern age (Stanford, CA, Stanford University Press).

Giddens, A. (1994) Living in a post-traditional society, in: U. Beck, A. Giddens \& S. Lash (Eds) Reflexive modernization: politics and tradition in the modern social order (Cambridge, Polity Press).

Held, D., McGrew, A. G., Goldblatt, D. \& Perraton, J. (1999) Global transformations: politics, economics and culture (Cambridge, Polity Press).

Hirst, P. \& Thompson, G. (1996) Globalization in question: the international economy and the possibilities of governance (Cambridge, Polity Press).

Kapstein, E. (1994) Governing the global economy: international finance and the state (Cambridge, MA, Harvard University Press).

Kleinknecht, A. \& ter Wengel, J. (1998) The myth of economic globalization, Cambridge fournal of Economics, 22, 637-647. 
Lafferty, G. \& Fleming, J. (2000) The restructuring of academic work in Australia: power, management and gender, British fournal of Sociology of Education, 21, 257-267.

Lash, S. (1993) Reflexive modernization: the aesthetic dimension, Theory, Culture and Society, 10, $1-23$.

Lash, S. (1999) Another modernity, a different rationality (Oxford, Blackwell).

Lichtblau, K. (1999) Differentiation of modernity, Theory, Culture and Society, 16, 1-30.

Lynch, M. (2001) Globalization and international democracy, International Studies Review, 2, 91-101.

Marginson, S. (1993) From cloister to market: the new era in higher education, fournal of Tertiary Education Management, 15, 43-62.

Marginson, S. (2000a) Research as a managed economy: the costs, in: T. Coady (Ed.) Why universities matter: a conversation about values, means and directions (St Leonards, Allen \& Unwin).

Marginson, S. (2000b) Re-thinking academic work in the global era, foumal of Higher Education Policy and Management, 22, pp. 23-35.

Marginson, S. (2000c) Living with the other: higher education in the global era, Australian Universities Review, 42, 5-8.

Marginson, S. \& Considine, M. (2000) The enterprise university: power, governance and reinvention in Australia (Oakleigh, Cambridge University Press).

Marginson, S. \& Rhoades, G. (2002) Beyond national states, markets and systems of higher education: A glonacal agency heuristic, Higher Education, 43, 281-309.

Martin, L. (1965) Tertiary education in Australia: Report of the Committee on the Funding of Tertiary Education in Australia (Canberra, Commonwealth of Australia).

McCalman, J. (2000) Blurred visions, in: T. Coady (Ed.) Why universities matter: a conversation about values, means and directions (St Leonards, Allen \& Unwin).

McCollow, J. \& Lingard, B. (1996) Changing discourses and practices of academic work, The Australian Universities' Review, 39, 11-19.

Mok, K. H. (2000) Impact of globalization: A study of quality assurance systems of higher education in Hong Kong and Singapore, Comparative Education Review, 44, 148-175.

Murray, K. (1957) Report of the Committe on Australian Universities (Canberra, Commonwealth of Australia).

Nelson, B. (2002a) Higher education at the crossroads (Canberra, Commonwealth of Australia).

Nelson, B. (2002b) Setting firm foundations: Financing Australian higher education (Canberra, Commonwealth of Australia).

Ohmae, K. (1995) The end of the nation state: the rise of regional economies (New York, Free Press).

Patience, A. (2000) Silencing the academy? Reflecting on a dispute in a corporatising university, Australian Universities Review, 43, 64-71.

Perraton, J., Goldblatt, D., Held, D. \& McGrew, A. (1997) The globalization of economic activity, New Political Economy, 2, 257-277.

Pratt, G. \& Poole, D. (2000) Global Corporations 'R' Us? The impacts of globalization on Australian universities, Australian Universities Review, 43, 16-23.

Readings, B. (1996) The university in ruins (Cambridge, MA, Harvard University Press).

Rose, N. (1999) Powers of freedom: reframing political thought (Cambridge, Cambridge University Press).

Slaughter, S. (1998) National higher education policies on a global economy, in: J. Currie \& J. Newson (Eds) Universities and globalization: critical perspectives (Thousand Oaks, CA, Sage).

Smyth, J. (1995) Introduction, in: J. Smyth (Ed.) Academic work: the changing labour process in higher education (Buckingham, Open University Press/SRHE).

Strydom, P. (1999) Hermeneutic culturalism and its double: a key problem in the reflexive modernization debate, European fournal of Social Theory, 2, 45-69.

Weiss, L. (1998) The myth of the powerless state (Ithaca, NY, Cornell University Press). 


\section{D. Pick}

West, R. (1997) Learning for life. Review of higher education financing and policy: a policy discussion paper (Canberra, Commonwealth of Australia).

Winter, R. \& Sarros, J. (2000) The academic work environment in Australian universities: a motivating place to work? Monash University Faculty of Business and Economic Working Paper Series 73/00 (Melbourne, Monash University).

Yang, R. (2000) Tensions between the global and the local: A comparative illustration of the reorganization of China's higher education in the 1950s and 1990s, Higher Education, 39, 319-337.

Zincone, G. \& Agnew, J. (2000) The second great transformation: the politics of globalization in the Global North, Space and Polity, 4, 5-21. 